\title{
Electronic library REV@ENF of the Network VHL Nursing International
}

\author{
Maria Helena Palucci Marziale
}

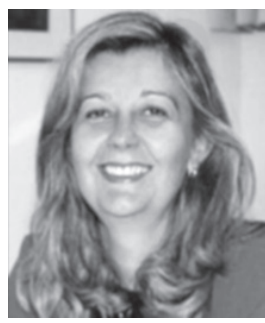

The University of São Paulo at Ribeirão Preto College of Nursing (EERP/USP) is celebrating its $60^{\text {th }}$ anniversary and, in the course of its existence, has conquered an outstanding position in the Brazilian and international scenario, due to the quality of its educational activities for nurses and researchers and its involvement in public and private institutions in health and education. As a Collaborating Centre of the World Health Organization for Nursing Research Development since 1998, the mission of EERP/USP is to contribute to the integration among nurses in Latin America, with scientific knowledge production and dissemination as strategies to achieve this goal.

In its efforts to disseminate the knowledge produced in Nursing, every two months, EERP/USP issues the Latin American Journal of Nursing, which is celebrating two decades of circulation this year and is currently ranked among the 20 most impacting Nursing journals around the world.

The College is also responsible for coordinating the Electronic Library REV@ENF, affiliated with the Virtual Health Library in Nursing (VHLN) International Network, a project that is part of VHL Nursing, put in practice by the institutions responsible for Nursing periodicals, with support from the Collaborating Centers of the VHL Nursing - BIREME Network and funding from the Brazilian Ministry of Health. This library joins a collection of Brazilian and international scientific Nursing journals, whose full text is available through open access within the SciELo method, and electronically, including the production of bibliometric statistics. The goals of REV@ENF are: to expand and strengthen scientific knowledge dissemination in Nursing, through universal and free access to selected scientific journals; to contribute to Brazilian and international health information policies, promoting the growth of the collection and user access facilities; guarantee the indexation of journals in the area; develop bibliometric studies and identify the impact of the publications; organize and systemize Nursing literature and improve, scientific production in Nursing in quantitative and qualitative terms.

Recently, VHL Nursing and REV@ENF were included in the World Health Organization (WHO)/Pan American Health Organization's (PAHO) Directorio de Redes Internacionales de Enfermería and new strategies were drawn to expand the number of journals indexed and the number of issues available.

Currently, 25 journals have been indexed in REV@ENF, 15 of which are published in Brazil, four in Spain, three in Colombia, one in Cuba, Chile and Portugal, respectively, adding up to 675 issues published and 12,280 papers, whose full text is available through open access at http://VHLenfermeria.VHLalud.org and http://www. portal.revenf.VHLalud.org/php/index.php?lang $=\mathrm{pt}^{(1-2)}$. 
REV@ENF is considered a strategy that strongly enhances the visibility, accessibility and credibility of scientific and technical production in Latin American Nursing, which even European countries are adhering to.

RLAE and the Electronic Journal Mental Health Alcohol and Drugs (SMAD), published EERP/USP, are members of REV@ENF.

\section{References}

1. Portal de Revistas de Enfermagem (REV@ENF) [internet]. São Paulo: VHL - BIREME-REVENF. [acesso em: 19 março 2013]. Disponivel em: http://www.portal.revenf.VHLalud.org/php/index.php?lang=pt.

2. Biblioteca Virtual em Saúde. VHL Enfermería Internacional. São Paulo: OPAS; UFMG;BIREME; MS. [acesso em: 19 março 2013]. Disponível em: http://VHLenfermeria.VHLalud.org.

Maria Helena Palucci Marziale is Chief Scientific Editor of the Revista Latino-Americana de Enfermagem and Full Professor of the Escola de Enfermagem de Ribeirão Preto, Universidade de São Paulo, WHO Collaborating Centre for Nursing Research Development, SP, Brazil. E-mail: marziale@eerp.usp.br. 